\title{
Some Hematological-Studice ON Diabetic RATS treated with certain hypoglycemic plants
}

\author{
Eman G.E. Helal*, Abeer S.M. Gawish**,A. Kahwash* \\ *Zoology Department. Faculty of science,Al -Azhar, University. \\ **Oral Medicine, Periodontology, Oral Diagnosis and Radiology department, Faculty of Dental \\ Medicine (girls section) Al- Azhar, University.
}

\begin{abstract}
The present study was designed to evaluate the effect of some antidiabetic plants on the hematological parameters in aloxan induced diabetes in albino rats.

Eighty adult albino rats $(120- \pm 20 \mathrm{gm}$ b.wt) were randomly divided into eight groups ten on each group, the first group conserved as control group. The remaining rats were injected with alloxan to induce diabetes. The second group conserved as diabetic group. The third group was diabetic rats treated with a mixture consists of Nigella Sativa, Aloe Vera, Ferula assa-foetida , Boswelli Carteri, Commiphora Myrrha. (0.1 ml/100gm b.wt),

Fourth group treated with $0.1 \mathrm{ml} / 100 \mathrm{gm} \mathrm{b.w}$ of Nigella Sativa, Fifth group treated with $0.05 \mathrm{ml} / 100 \mathrm{gm}$ b.w of Aloe Vera,Sixth group treated with $0.1 \mathrm{ml} / 100 \mathrm{gm}$ b.w of Ferula assafoetida, Seventh group treated with $0.1 \mathrm{ml} / 100 \mathrm{gm} \mathrm{b.w}$ of Boswelli Carteri, Eighth group treated with $0.1 \mathrm{ml} / 100 \mathrm{gm}$ b.w of Commiphora Myrrha. Haematological parameters includes: red blood cell count (RBCs), hemoglobin concentration ( $\mathrm{Hb})$, hematocrit value (Hct\%), total and differential white blood cell cont (WBCs) were done after 30 days of treatment and after 15 days of recovery period.

The result of RBCs count, $\mathrm{Hb}$ concentration and Hct value were significantly decreased in diabetic, Nigella Sativa and Aloe Vera treated groups, throughout the experiment, except Aloe Vera treated group showed insignificant change after the recovery period.while insignificant changes was recorded in the remnant groups during the experimental period.

WBCs count, lymphocyte and neutrophil percentage were highly significant increased in diabetic and Ferula assa-foetida treated rats after treatment and recovery periods. While insignificant differences were observed in the other treated groups. Moreover, no significant changes were recorded in eosinophils and monocytes in all groups throughout the study period.

Diabetes mellitus in experimental animal can be treated with some plants which have antidiabetic effect, the present investigation was designed to illustrate any hazard effect of these plants on some hematological parameter. Further investigations on each plant and their mixture are needed to role out its effect on both diabetes and the vital parameters.
\end{abstract}

\section{Introduction}

For long time ago, many plants and plant extracts which posses marked hypoglycemic activity have been tried in the treatment of diabetes mellitus in folk medicine (Asmal\&Marble, 1984). More than 400 traditional plant treatment $\mathrm{s}$ have been recorded, but only a small part of these plants have been investigated scientifically and medically evaluate their efficacy (Lot-likar \&Rajaram,1966).
A scientific investigation of herbal remedies for diabetes mellitus may be helpful in the development of alternative therapeutic strategies (Marls\& Farnsworth, 1995).

A number of plants have been shown to exhibit hypoglycemic activity with animal models.

Nigella Sativa has been used as a natural medicine for treatment of diabetes, 


\section{Same Hematological-Studice ON Diabetic RATS...}

hypertension as well as some dermatologic conditions (Meral et al,2001).

Aloe Vera has been used all over the world for their various medicinial properties. However, there have been controversial reports about its hypoglycemic properties, which may be due to the differences in the parts of the plant used or to the model of diabetic chosen (Okyar et al, 2001).

Ferula assa-foetida, the asafoetida's Olea-gum-resin are the main parts used, the volatile oil contains disulphaides. The sulpher compounds in the oil may protect against fat induced hyperlipdemia (Duke, 2002).

Comiphora Myrrha, the myrrh's gumresin- volatile oil are the main used parts. It is an excellent remedy for hyperglycemia (Chevallier, 1996 \&Duke,2002).

A water extract of a mixture of the above mention five plants were studied for identification of its active components(Al Awadi\& Shoukry 1988). Only the extracts of myrrh and Olea gums effectively increased glucose tolerance in both normal and diabetic rats. While the remaining components showed no effect.

Alloxan was found to be selectively $\beta$ cytotoxic agents in animals, extremely potent diabetogenic substance and may induce hemolysis of red blood cell in experimental animals (Okamoto, 1984).

The present investigation was carried out to illustrate if any one of these plant extracts has any hazard effect on hematological picture.

\section{Materials and Methods}

The present study was carried out on eighty male albino rats weights $120 \pm 20$ grams of local strain from NAMRU medical center. They were divided into eight groups (10/ group).

\section{Preparation of the mixture:}

Plants were grinded and $10 \mathrm{gm}$ of each plant were mixed and boiled in $100 \mathrm{ml}$ water for a period of $10 \mathrm{~min}$ then cooled at room temperature and filtered. The extract was given orally with a dose of $1 \mathrm{ml} / 100$ gm b.w (by using the incubation tube , every day till 30 days). This dose equal to the therapeutic dose related to human dose (Paget and Barnes, 1964).

Group I serve as control

The remaining 70 fasting rats over night were injected with subcuta-neous dose of alloxan (120/kg b.wt) to induce diabetes .After 48 hours blood glucose level were measured by glucometer , diabetes was consi-derd as blood glucose $\geq 250 \mathrm{mg} / \mathrm{dl}$

Group II served as diabetic.

GroupIII diabetic rats treated with mixture of treatment plants $(0.1 \mathrm{ml} / 100 \mathrm{gm} \mathrm{b} . \mathrm{w})$

Group IV diabetic rats treated with $0.1 \mathrm{ml} / 100 \mathrm{gm}$ b.w of Nigella Sativa

Group $\mathbf{V}$ diabetic rats treated with $0.05 \mathrm{ml} / 100 \mathrm{gm}$ b.w of Aloe Vera

Group VI diabetic rats treated with $0.1 \mathrm{ml} / 100 \mathrm{gm}$ b.w of Ferula assafoetida

Group VII diabetic rats treated with $0.1 \mathrm{ml} / 100 \mathrm{gm}$ b.w of Boswelli Carteri

Group VIII diabetic rats treated with $0.1 \mathrm{ml} / 100 \mathrm{gm}$ b.w of Commiphora Myrrha

After 30 days of treatment (treatment period), 5 animals of each group were sacrificed, while the other half of each group was kept for 15 days more without any treatment to follow up if there is any delayed effect (recovery period ).

\section{Hematological assessment}

Two blood samples were taken from each rat: after both the treated period and the recovery period

\section{The following analyses were done}

1- Estimation of hemoglobin concentration (Drabkin \&Austin, 1932)

2-Measurment of hematocrit value (Hct) (Rodak ,1995) by using heparinized capillary tube

3- Red blood corpuscles count (RBCs) visually counted according to Dacie \& Lewis (1991) method

4- White blood cell count (WBCs) visually counted according to Mitruka et al., 1977) 
5- Calculation of differential leucocytic count, were done according to Dacie $\&$ Lewis (1991)

All the data were statistically analyzed using student $t$ test.

\section{Results}

The present study showed highly significant decrease $(p<0.01)$ in RBCs count, $\mathrm{Hb}$ concentration and Hct value in diabetic rats compared with control group during the experimental period (table 1)

Moreover, the groups treated with mixture, Ferula assa-foetida Boswellia Carterii Birdw \& Comiphora Myrrha showed insignificant changes in RBCs count, $\mathrm{Hb}$ concentration and Hct values as compared with control group, while there was a highly significant increase $(\mathrm{p}<0.01)$ when compared with diabetic group throughout the experiment .

Nigella Sativa treated group showed highly significant decrease $(\mathrm{p}<0.01)$ in $\mathrm{RBCs}$ count ,Hb concentration and $\mathrm{Hct}$ value when compared with controls group,and no significant changes was recorded in these parameters when compared with diabetic group.

On the other hand, the group treated with Aloe vera showed significant decreae $(\mathrm{p}<0.05)$ in $\mathrm{RBCs}$ count, $\mathrm{Hb}$ concentration and Hct value when compared with controls group after treated period,and no significant changes was recorded after recovery period . However, there was a significant increase $(\mathrm{p}<0.05)$ in these parameters after recovery period when compared with diabetic group. (Table 1,2 )

Table (1) : Red blood cell count (RBcs),Hemoglobin conc.(Hb) And Hematocit value (Hct) in control, diabetic and plant extract treated groups after 4 weeks (treated period)

\begin{tabular}{|c|c|c|c|c|c|c|c|c|c|}
\hline \multirow{2}{*}{\multicolumn{2}{|c|}{ Group }} & \multicolumn{8}{|c|}{ Treated period (4weeks) } \\
\hline & & \multirow{2}{*}{\begin{tabular}{|c|} 
control \\
$\mathbf{7 . 5 8}$
\end{tabular}} & \multirow{2}{*}{$\begin{array}{c}\text { diabetic } \\
\mathbf{5 . 6 5}\end{array}$} & \multirow{2}{*}{$\begin{array}{c}\text { mixture } \\
7.56\end{array}$} & \multirow{2}{*}{$\begin{array}{c}\begin{array}{c}\text { Nigella } \\
\text { stavia }\end{array} \\
5.74 \\
\end{array}$} & \multirow{2}{*}{$\begin{array}{l}\text { Aloe } \\
\text { vera }\end{array}$} & \multirow{2}{*}{$\begin{array}{c}\begin{array}{c}\text { Ferula } \\
\text { Assa- } \\
\text { foetida }\end{array} \\
6.75\end{array}$} & \multirow{2}{*}{$\begin{array}{c}\begin{array}{c}\text { Boswellia } \\
\text { carterii } \\
\text { Birdw }\end{array} \\
6.95\end{array}$} & \multirow{2}{*}{$\begin{array}{c}\begin{array}{c}\text { Commiphora } \\
\text { myrrh }\end{array} \\
\mathbf{7 . 0 4}\end{array}$} \\
\hline \multirow{4}{*}{$\begin{array}{c}6 \\
\text { RBCs X10 }\end{array}$} & mean & & & & & & & & \\
\hline & \pm SD & 0.15 & 0.21 & 0.14 & 0.16 & 0.26 & 1.22 & 1.07 & 1.08 \\
\hline & A & & $* *$ & & $* *$ & $*$ & & & \\
\hline & B & & & $* *$ & & * & $* *$ & $* *$ & $* *$ \\
\hline \multirow{4}{*}{$\mathrm{Hb}(\mathrm{gm} \%)$} & mean & 14.8 & 12.08 & 14.66 & 11.64 & 13.86 & 14.58 & 14.76 & 14.58 \\
\hline & \pm SD & 0.25 & 0.31 & 0.02 & 0.43 & 0.25 & 0.22 & 0.27 & 0.19 \\
\hline & $\mathbf{A}$ & & $* *$ & & $* *$ & $*$ & & & \\
\hline & $\mathbf{B}$ & & & $* *$ & & $*$ & $* *$ & $* *$ & $* *$ \\
\hline \multirow{4}{*}{ Hct $\%$} & mean & 48.40 & 40.24 & 47.98 & 38.92 & 44.60 & 48.96 & 48.32 & 49.12 \\
\hline & \pm SD & 0.75 & 1.01 & 0.07 & 1.30 & 1.45 & 0.54 & 0.64 & 0.33 \\
\hline & $\mathbf{A}$ & & $* *$ & & $* *$ & $*$ & & & \\
\hline & B & & & $* *$ & & $*$ & $* *$ & $* *$ & $* *$ \\
\hline
\end{tabular}

A- in comparison with control group

$\mathrm{B}$-in comparison with diabetic group

* Significant $(\mathrm{p}<0.050$

** Highly significant $(\mathrm{p}<0.01)$ 
Table( 2) : Red blood cell count (RBcs) ,Hemoglobin conc. (Hb) And Hematocit value (Hct) in control ,diabetic and plant extract treated groups after recovery period (2 weeks)

\begin{tabular}{|c|c|c|c|c|c|c|c|c|c|}
\hline \multirow{2}{*}{\multicolumn{2}{|c|}{ Parameter }} & \multicolumn{8}{|c|}{ Recovery period (2weeks) } \\
\hline & & \multirow{2}{*}{$\begin{array}{c}\text { control } \\
7.16\end{array}$} & \multirow{2}{*}{$\begin{array}{c}\text { diabetic } \\
5.97\end{array}$} & \multirow{2}{*}{$\begin{array}{c}\text { mixture } \\
7.12\end{array}$} & \multirow{2}{*}{$\begin{array}{c}\begin{array}{c}\text { Nigella } \\
\text { stavia }\end{array} \\
5.92\end{array}$} & \multirow{2}{*}{$\begin{array}{c}\text { Aloe } \\
\text { vera }\end{array}$} & \multirow{2}{*}{$\begin{array}{c}\begin{array}{c}\text { Ferula } \\
\text { Assa-foetida }\end{array} \\
7.15\end{array}$} & \multirow{2}{*}{$\begin{array}{c}\begin{array}{c}\text { Boswellia } \\
\text { carterii } \\
\text { Birdw }\end{array} \\
7.27\end{array}$} & \multirow{2}{*}{$\begin{array}{c}\begin{array}{c}\text { Commiphora } \\
\text { myrrh }\end{array} \\
\mathbf{7 . 1 6}\end{array}$} \\
\hline \multirow{4}{*}{$\begin{array}{c}\text { RBCsX } \\
10^{6}\end{array}$} & mean & & & & & & & & \\
\hline & \pm SD & 0.09 & 0.07 & 0.10 & 0.06 & 0.16 & 0.04 & 0.07 & 0.03 \\
\hline & A & & ** & & $* *$ & ** & & & \\
\hline & B & & & ** & & ** & ** & $* *$ & ** \\
\hline \multirow{4}{*}{$\begin{array}{c}\mathrm{Hb}(\mathrm{gm} \\
\% 0)\end{array}$} & mean & 15.38 & 11.36 & 14.84 & 11.85 & 14.34 & 14.82 & 14.72 & 14.78 \\
\hline & \pm SD & 0.31 & 0.04 & 0.31 & 0.09 & 0.39 & 0.12 & 0.29 & 0.31 \\
\hline & $\mathbf{A}$ & & ** & & ** & & & & \\
\hline & B & & & ** & & ** & ** & ** & ** \\
\hline \multirow{4}{*}{ Hct $\%$} & mean & .1450 & 43.08 & 49.32 & 44.86 & 47.56 & 47.56 & 48.90 & 45.25 \\
\hline & \pm SD & 0.85 & 1.05 & 0.47 & 0.91 & 0.82 & 0.37 & 1.01 & 0.48 \\
\hline & $\mathbf{A}$ & & ** & & $* *$ & & & & \\
\hline & B & & & ** & & ** & ** & ** & ** \\
\hline
\end{tabular}

A- in comparison with control group

$\mathrm{B}$-in comparison with diabetic group

* Significant $(\mathrm{p}<0.05)$

$* *$ Highly significant $(\mathrm{p}<0.01)$

Total and differential white blood cells count:

Concerning white blood cell count the present data showed a significant increase $(\mathrm{p}<0.05)$ in diabetic group which was highly significant $(\mathrm{p}<0.01)$ after recovery period when compared with control group (table $3 \& 4$ )

Diabetic group showed insignificant changes in the percentage of eosinophils, monocyte and staff neutrophils, however, there was highly significant increase $(\mathrm{p}<0.01)$ in segmented neutrophils. Lymphocytes showed highly significant decrease $(p<0.01)$ when compared with control group throughout the experimental period.

The groups treated with mixture, Nigella Sativa, Aloe Vera ,Boswellia

Carterii Birdw \& Comiphora Myrrha showed insignificant change in their count when compared with control group during the experiment, while a significant decrease $(p<0.05)$ was recorded after the treatment period and showed highly significant decrease $(\mathrm{p}<0.01)$ after recovery period when compared with diabetic group

Concerning the percentage of eosinophils, neutrophils (Staff and Segmented) ,monocyte and lymphocytes insignificant change had been recorded in treated groups when compared with control group during the experimental period. However, when compared with diabetic group a high significant decrease was detected in segmented neutrophils $(\mathrm{p}<0.01)$ and high significant increase $(p<0.01)$ in lymphocytes, while the percentage of eosinophils, staff neutrophils and monocytes showed insignificant changes.

On the other hand, the group treated with , Ferula assa-foetida showed significant increase in its WBCs count when compared to control group, while insignificant changes was clear when 
compared to diabetic group duing the study period.

Concerning the percentage of eosinophils, staff neutrophils and monocyte showed insignificant change Ferula assa-foetida treated group when compared with control group during the experimental period. However, Segmented Neutrophils showed high significant increase $(\mathrm{p}<0.01)$ as comp- ared with control group and insignificant change when compared with diabetic group.

Lymphocytes showed high significant decrease $(\mathrm{p}<0.01)$ as compared with control group and insignificant change when compared with diabetic group allover the study period (Table 3\&4).

Table (3) : White blood cells count and differential leucocytic count (Eosinophils, Segmented neutrophils, Staff neutrophils ,Monocyte and Lymphocyte)in control ,diabetic and plant extract treated groups after 4 weeks (treated period)

\begin{tabular}{|c|c|c|c|c|c|c|c|c|c|}
\hline \multirow{2}{*}{\multicolumn{2}{|c|}{ Parameter }} & \multicolumn{8}{|c|}{ Treated period (4weeks) } \\
\hline & & control & diabetic & Mixture & $\begin{array}{c}\text { Nigella } \\
\text { stavia }\end{array}$ & $\begin{array}{l}\text { Aloe } \\
\text { vera }\end{array}$ & $\begin{array}{c}\text { Ferula } \\
\text { Assa- } \\
\text { foetida }\end{array}$ & $\begin{array}{c}\text { Boswellia } \\
\text { carterii } \\
\text { Birdw } \\
\end{array}$ & $\begin{array}{c}\text { ommiphora } \\
\text { myrrh }\end{array}$ \\
\hline \multirow{4}{*}{ WBCsX10 } & mean & 7.53 & 9.33 & 7.64 & 7.41 & 7.85 & 9.27 & 8.01 & 8.09 \\
\hline & \pm SD & 0.95 & 0.33 & 0.45 & 0.70 & 0.47 & 0.26 & 0.38 & 0.36 \\
\hline & $\mathbf{A}$ & & $*$ & & & & $*$ & & \\
\hline & B & & & $*$ & $*$ & $*$ & & $*$ & $*$ \\
\hline \multirow{4}{*}{$\begin{array}{l}\text { Eosinophil } \\
\mathrm{s} \%\end{array}$} & mean & 0.83 & .460 & 0.73 & 0.53 & 0.67 & 0.80 & 0.50 & 0.57 \\
\hline & \pm SD & 0.31 & 0.21 & 0.31 & 0.21 & 0.29 & 0.28 & 0.22 & 0.24 \\
\hline & $\mathbf{A}$ & & - & - & - & - & - & - & - \\
\hline & B & & & - & - & - & - & - & - \\
\hline \multirow{4}{*}{$\begin{array}{l}\text { Segmented } \\
\text { neutrophils }\end{array}$} & mean & .3330 & .1457 & 31.33 & 25.33 & 29.50 & 55.50 & 27.67 & 28.50 \\
\hline & \pm SD & 2.23 & 2.29 & 2.42 & 3.96 & 2.96 & 3.96 & 1.96 & 2.22 \\
\hline & $\mathbf{A}$ & & $* *$ & & & & $* *$ & & \\
\hline & B & & & $* *$ & $* *$ & $* *$ & & $* *$ & $* *$ \\
\hline \multirow{4}{*}{$\begin{array}{l}\text { Staff } \\
\text { neutrophils }\end{array}$} & Mean & 1.17 & 1.32 & 0.77 & 0.85 & 0.83 & 1.53 & 0.88 & 0.78 \\
\hline & \pm SD & 0.33 & 0.42 & 0.31 & 0.31 & 0.31 & 0.18 & 0.42 & 0.45 \\
\hline & A & & - & - & - & - & - & - & - \\
\hline & B & & & - & - & - & - & - & - \\
\hline \multirow{4}{*}{ Monocyte } & mean & 2.69 & 1.67 & 2.29 & 2.66 & 2.00 & 1.96 & 2.02 & 2.92 \\
\hline & \pm SD & 0.43 & 0.56 & 0.73 & 0.23 & 0.73 & 0.43 & 0.33 & 0.62 \\
\hline & $\mathrm{A}$ & & - & - & - & - & - & - & - \\
\hline & $\mathrm{B}$ & & & - & - & - & - & - & - \\
\hline \multirow{4}{*}{$\begin{array}{l}\text { Lymphocyt } \\
\text { e }\end{array}$} & mean & 64.98 & 39.01 & 64.87 & 71.02 & 67.00 & 40.21 & 68.93 & 67.23 \\
\hline & \pm SD & 1.92 & 2.96 & 1.75 & 3.71 & 2.13 & 2.98 & 1.72 & 1.53 \\
\hline & $\mathrm{A}$ & & $* *$ & & & & $* *$ & & \\
\hline & B & & & $* *$ & $* *$ & $* *$ & & $* *$ & $* *$ \\
\hline
\end{tabular}

A- in comparison with control group

$\mathrm{B}$-in comparison with diabetic group

* Significant $(\mathrm{p}<0.05)$

** Highly significant $(\mathrm{p}<0.01)$

- Insignificant 


\section{Same Hematological-Studice ON Diabetic RATS...}

Table (4) : White blood cells count and differential leucocytic count (Eosinophils, Segmented neutrophils, Staff neutrophils, Monocyte and Lymphocyte)in control ,diabetic and plant extract treated groups after recovery period( 2 weeks)

\begin{tabular}{|c|c|c|c|c|c|c|c|c|c|}
\hline \multirow{2}{*}{\multicolumn{2}{|c|}{ group }} & \multicolumn{8}{|c|}{ Recovery period ( 2 weeks) } \\
\hline & & \multirow{2}{*}{$\begin{array}{r}\text { control } \\
\mathbf{7 . 8 6}\end{array}$} & \multirow{2}{*}{$\begin{array}{r}\text { diabetic } \\
\mathbf{1 0 . 8 3}\end{array}$} & \multirow{2}{*}{$\begin{array}{c}\text { mixture } \\
7.38\end{array}$} & \multirow{2}{*}{$\begin{array}{c}\begin{array}{c}\text { Nigella } \\
\text { stavia }\end{array} \\
7.52\end{array}$} & \multirow{2}{*}{$\begin{array}{l}\begin{array}{l}\text { Aloe } \\
\text { vera }\end{array} \\
7.77\end{array}$} & \multirow{2}{*}{$\begin{array}{c}\begin{array}{c}\text { Ferula } \\
\text { Assa- } \\
\text { foetida }\end{array} \\
\mathbf{9 . 3 4}\end{array}$} & \multirow{2}{*}{$\begin{array}{c}\begin{array}{c}\text { Boswellia } \\
\text { carterii } \\
\text { Birdw }\end{array} \\
7.88 \\
\end{array}$} & \multirow{2}{*}{$\begin{array}{c}\begin{array}{c}\text { Commiph } \\
\text { ora myrrh }\end{array} \\
\mathbf{8 . 0 6}\end{array}$} \\
\hline \multirow{4}{*}{ WBCs } & mean & & & & & & & & \\
\hline & \pm SD & 0.47 & 0.13 & 0.32 & 0.26 & 0.38 & 0.25 & 0.34 & 0.36 \\
\hline & $\mathbf{A}$ & & & & & & * & & \\
\hline & B & & & $* *$ & $* *$ & $* *$ & & $* *$ & $* *$ \\
\hline \multirow{4}{*}{ Eosinophils\% } & mean & 0.88 & .430 & 0.83 & 0.60 & 0.60 & 0.67 & 0.72 & 0.67 \\
\hline & \pm SD & 0.45 & 0.33 & 0.65 & 0.34 & 0.34 & 0.42 & 0.52 & 0.42 \\
\hline & $\mathbf{A}$ & & - & - & _ & _ & _- & - & - \\
\hline & B & & & & & & & & \\
\hline \multirow{4}{*}{$\begin{array}{l}\text { Segmented } \\
\text { neutrophils }\end{array}$} & mean & .6230 & 60.63 & 31.17 & 27.78 & 30.31 & 50.57 & 29.33 & 32.83 \\
\hline & \pm SD & 0.96 & 3.96 & 1.05 & 1.86 & 2.22 & 3.21 & 1.75 & 2.83 \\
\hline & $\mathbf{A}$ & & $* *$ & & & & $* *$ & & \\
\hline & B & & & $* *$ & ** & $* *$ & & $* *$ & $* *$ \\
\hline \multirow{4}{*}{$\begin{array}{l}\text { Staff } \\
\text { neutrophils }\end{array}$} & mean & 1.50 & 1.60 & 1.36 & 0.83 & 1.00 & 1.47 & 1.17 & 1.50 \\
\hline & \pm SD & 0.34 & 0.45 & 0.40 & 0.40 & 0.68 & 0.54 & 0.45 & 0.02 \\
\hline & A & & - & - & - & - & - & - & - \\
\hline & B & & & - & - & - & - & - & - \\
\hline \multirow{4}{*}{ Monocyte } & mean & 2.55 & 1.67 & 2.17 & 7.73 & 2.16 & 1.57 & 2.12 & .093 \\
\hline & \pm SD & 0.62 & 0.65 & 0.33 & 1.50 & 0.62 & 0.33 & 0.42 & 0.62 \\
\hline & A & & -- & - & - & $\begin{array}{lll}- & \\
-\end{array}$ & $\begin{array}{lll}- & \\
-\end{array}$ & $\begin{array}{lll}- & \\
-\end{array}$ & - \\
\hline & B & & & - & - & - & - & - & - \\
\hline \multirow[t]{4}{*}{ Lymphocyte } & mean & 64.45 & 35.68 & 64.47 & 68.26 & 66.13 & 45.74 & 66.65 & 61.91 \\
\hline & \pm SD & 1.52 & 1.65 & 2.54 & 2.39 & 1.84 & 1.34 & 3.33 & 2.07 \\
\hline & $\mathrm{A}$ & & $* *$ & & & & $* *$ & & \\
\hline & B & & & $* *$ & $* *$ & $* *$ & $* *$ & $* *$ & $* *$ \\
\hline
\end{tabular}

A- in comparison with control group

$\mathrm{B}$-in comparison with diabetic group

* Significant $\mathrm{p}<0.05$

** Highly significant $\mathrm{p}<0.01$

\section{Discussion}

The traditional antidiabetic plants might provide useful source of new oral hypoglycemic compounds. The antidiabetic action of plant extract may be mediated through decreased hepatic gluconeogenesis (Al Awadi et al, 1991).

The present study is a step to_evaluate and follow up the effect of these plant extracts on some hematological parameter.

The present results showed that diabetic rats recorded a decrease in RBCs

count, $\mathrm{Hb}$ content and $\mathrm{Hct}$ value .These rats suffered from anemia which may be results from the toxic effect of alloxan used to induce diabetes in these rats. This anemia could be attributed to destruction of RBCs and reduced rate of its release from the bone marrow to blood. Several studies attributed this anemia to increase in lipid peroxidation of the erythrocyte cell membrane (Kang-Xin et al.,1990 and Helal, 2000). 


\section{Eman G.E. Helal et al}

The results of the present investigation showed significant decrease in $\mathrm{RBCs}, \mathrm{Hb}$ and Hct value in Nigella Stavia (N.S)treated group. The lower serum iron might be due to the effect of N.S which deprives iron from body fluid to be conjugated with proteins. This was contradictory with Hedaya (1995) who found that low dose of N.S extract caused significant increase in $\mathrm{Hb}, \mathrm{PCV}$ and $\mathrm{RBCs}$

Tizard (1995) mentioned that iron is essential for bacterial invasion to the body in which, iron is associated with iron binding protein transferring, lactoferrin, heptaglobin and feritin. The lower serum iron in the present investigation might be due the effect of N.S. which eliminate iron from the body fluid to be conjugated with proteins. This may be due to the antibacterial effect of N.S as reported by El-Fatatry (1975), Hanafy \& Hatem (1991) and Kandil et al (1994)

Otherwise, a general decrease in all hematological parameters in the diabetic state was ameliorated by the treatment with mixture, Aloe vera, Bosweelia Carterri Bidw and Commiphora Myrrha. This indicates that these plants could reduce the destructive effect of alloxan .

The total WBCs count in diabetic group showed a significant increase. This increase in total WBCs count may be due to the increased hemopoitic activity as a result of the hemolysis of RBCs in diabetic rats.In the diabetic group, lymphocytes were decreased in number. This may be as a response to stressful condition after antigen (alloxan) injection which was in agreement with Sovneyl et al., 1990, or it may be due to the production of specific or non specific antibodies against different antigens, since lymphocytes are responsible for achieving the defense mechanism in the body (El Feki et al.,1997).

The increasing of neutrophil number may be due the engagement of these cells in the phagocytic process against different antigens. The increase in neutrophils also may be due to decrease its phagocytic activity in hyperglycemia and due to increase in hemopoitic activity after releasing the granules of neutrophil by exocytosis to lyses the antigens extracellularly (Ganong,2003).
Ferula ass.foetida showed an improvement in percentage of lymphocytes when compared to diabetic group. This may be attributed to ass-foetida's volatile oil which contain sodium ferulate which prev-ent lymphocytes apoptosis( $\mathrm{Lu}$ et $a l, 1998)$, and activate the lymphoid tissues of the body to form lymphocytes. This is in accordance with Chevallier (1996) who mentioned that ass-foetida's volatile oil, has antibiotic action and acts as immunoenhancer.

In the present result, mixture, Nigella Stavia, Aloe vera, Bosweelia Carterri Bidw and Commiphora Myrrha treated groups showed an increase (turned back to normal value) in WBCs count, neutrophils percentage and a decrease in lymphocytes, this may be due to the changes in the immunological parameters achieved by plant extracts during diabetes and after treatment period. This indicates that the treatment with plants affect the defense mechanism and immune response to inhibits the inflammation resulting from alloxan treatment .This is in accordance with Kollar \&Roan, 1980 and Shakoori et al., 1992.

From the present study, the use of, Aloe vera, Bosweelia Carterri Bidw and Commiphora Myrrha could ameliorate the damage effect of aloxan.Using Nigella Stavia increase, the hazards state which turn back to normal value after stopping the usage of the plant extract. So, it is well recommended not to use Nigella Stavia in anemic patients.

\section{References}

1. Ajagaokar, S.S(1979): Herbal drugs in the treatment of diabetes; IDF. Bulletine, 14:10-17.

2. Al-Awadi, F.M.and Shoukry, M.(1988): The lipid lowering effect of an antidiabetic plant extract. Acta. Diabetol. Lat.,25:1-5

3. Al-Awadi, F.M.; Farania,H. and Shamte, U.(1991): The effect of a plants mixture on liver gluconeogensis in streptozotocin induced diabetic rats. Diabetes Research, 18:163-168

4. Asmal, A.C. and Marble, A.(1984): The oral hypoglycemic agents. Drugs, 28:62-78

5. Chevallier, A.(1996): The encyclopedia of medicinal plants. $1^{\text {st }}$ American ed $\mathrm{Pp}$ 6,237.

6. Dacie, J.V.and Lewis, S.M.(1991): Hematology $.7^{\text {th }}$ ed., the English language book socity and Churchill lirringstone:36-58. 
7. Drabkin, D.L. and Austin, J.H.(1932) : Spectrophotometric studies: Spectrophotometer constants for common hemoglobin derivatives in human, dog and rabbit .J.Biol.Chem., 98:719-752.

8. Duke, J.A.(2002): Hand book of medicinal herbs. $2^{\text {nd }}$ ed. United states of America, Pp.:15-519

9. El-Fatatry, M. N. (1975): Isolation and structure assignment of an antimicrobial principle from volatile oil of Nigella Sativa L.seeds. Pharmacies, 30:109-111

10. El-Feki, M.A.; Radwan, Z.A.; AbdelMoneim, A.A.and Salah, E.M.(1997): Effect of Nigella Sativa and fish oil on alloxan diabetic rats:2- Immunological studies. J.Egypt. Ger.Soc.Zool., 23(A):161-186

11. Ganong, W.F.(2003): Review of medical physiology $23^{\text {rd }}$ ed., Lange med. Public, 19:306-326

12. Hanafy, M.S. and Hatem M.F(1991); Studies of antimicrobial activity of Nigella Sativa seed (Black cumin).J. Ethenopharmacol. 34(2-3): 275-278.

13. Hayashi, S.(1998): Essential oil of Bowsellia. The Journal of Essential Oil Research, 10:25-30.

14. Hedaya S.A.(1995): Effect of Nigella seeds (black seed) extract on some ematological and biochemical parameters in rats. Alexandria. J. Veter. Science, 11:95-99.

15. Helal, E.G.E.(2000): Effectiveness of an herbal mixture with treatment of noninsulin dependent diabetes mellitus. AlAzhar Bull.Sc., 1:201-234

16. Kandil, O., Radwan , N.; Hassan, A.B.; Aziza, M.M; El-Banna, H.A. and Wafaa, M.M.(1994): Antimicrobial activity of Nigella Sativaand Zinger officinal. Veter. Med.J., 42:159-168.

17. Kang-xin, Fang-Yunzhong, XinWanjuan and Sunchunr P.U.(1990): Observation on the effect of irradiation in vitro and in vivo on SH- group of rat erythrocyte membrane by spine label technique. J. Radia. Res. And Radia process, 8(2): 103-112.

18. Kollar, L.D. and Roan, J.G.(1980): Responses of lymphocyte from lead, cadmium and methyl mercury exposed mice in mixed lymphocyte culture. J.Environ.Pathol. Toxico.4;393-398.

19. Lot-likar, M.M and Rajarama-Rao, m.R.(1966): Pharmacology of hypoglycemic principle isolated from fruits of momordia chranti, linn, Ind. J. Pharmacy,28-129.

20. Lu,Y.; Xu,Yang, Y. and Pan H.(1998): The effect of antioxidant sodium ferulate on human lymphocytes apoptosis induced by H2O2.Zhongguo. Yi.Xue. Ke.Xue. Yuan. Xue .bao.,20(1) :44-48.
21. Marles R.T. and Farnsworth, N.R. (1995): Antidiabetic plants and their active constituents.Phytomedicine,2:137-189.

22. Meral, I.; Yener, Z.; Kahraman, T. and Mert, N.(2001): Effect of Nigella Sativa on glucose concentration, lipid peroxidation , antioxidant defence system and liver damage in expermintally induced diabetic rabbits. J.Vet. Med.A.Physiol.pathol. Clin.med. 48(10)593-599.

23. Mitruka, B.m; Rawnsley, H.M.and Vaderha, B.V.(1977): Clinical biochemical and hematological reference value in normal experimental animals. Masson publishing USA.

24. Okamoto, H.(1984) : Molecular basis of experimental diabetes: DDegeneration, oncogenesis and regeneration of pancreatic $\beta$ cell of islet of langerhans. Bio.Essays, 2:15-21.

25. Okyar, A.; Akev,N.; Baktir, G. and Sutlupinar, N.(2001): Effect of Aloe vera leaves on blood glucose level in type I and type II diabetic rat models. Phytother. Res., 15(2):157-161.

26. Olefsky,J.M.(1981): insulin resistance and insulin action. An in vitro perspective. Diabetes, 30:148-162.

27. Paget,G.E and Barnes,J.M.(1964): Evaluation o drug activities pharmaco-metrics. $1^{\text {st }}$ ed. Laurence, D.R. and Bacharach, A.L., Academic press, London and New York.

28. Rodake, F.P.(1995); Routine laboratory evaluation of blood cells and bone marrow. In diagnostic hematology. W.B.Lid London.Pp:125-129

29. Shakoori, A.R.; Butt, U.; Riffat, R. and Aziz, F. (1992): Toxic effects of shortterm oral administration of alloxan on the blood and liver of rabbits. Punjab. Univ. J.Zool., 13:26

30. Svenyl, J.F..; Yamamato, h.; Fujimoto, S. and Kusuda, R. (1990): lymphomyeloid cells, susceptibility to erythrodermatitis of Carp and bacterial antigens. Dev. Comp. immunol., 14:185-220.

31. Tayhurn, P.; Good body, A.E. and James, W.P.T.(1982): A role for brown adipose tissue in the genesis of Proc. Nutr. Soc., 41;127-131.

32. Tizard,I.R.91995):immunology, an introduction, $3^{\text {rd }}$ ed.,W.B,Saunders Co.,New York

33. Vignati L.and Cunningham, L.N.(1985): Exercise and diabetes. In Joslin's diabetes mellitus, $12^{\text {th }}$ ed. Marble A. Krall, L.P.; Bradely, R.F.; Christ Lied, A.P. Soledner, J.S.(eds) Philadelphia P.A. lea and Febiger. Pp:453-464.

34. Williams, G. and Pickup J.C.(1999): Hand book of diabetes . black well science. Aveatis 


\section{بعض قياسات الام في الفئران البيضاء المصابة بالسكر

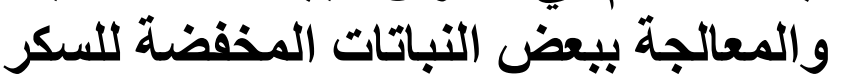

* (ايمان جمال الاين هلال ، ** عبير سعد محمد جاويش ، * أنوار الكامل كحوش الزي

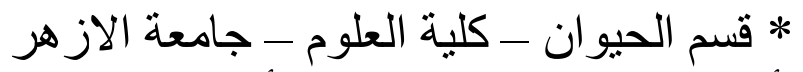

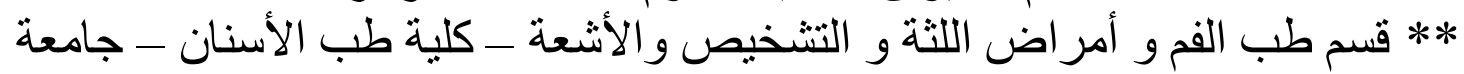
الازهر

أجري هذا البحث لدر اسة مدي فعالية بعض النباتات التي تستخدم كمخفضـات لسكر الدم و

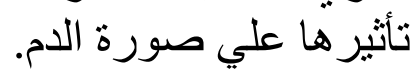

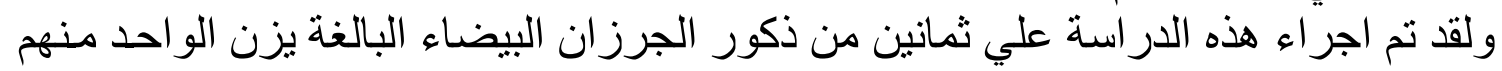

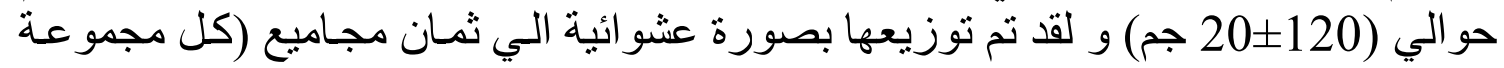
تحتوي علي 10 جرذان كالاتي:

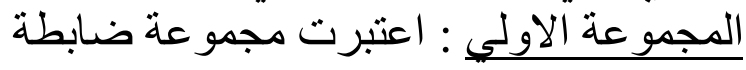

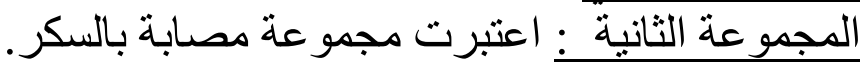

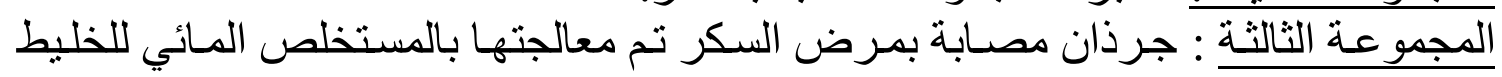

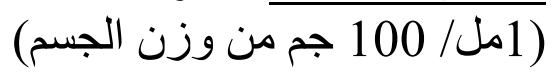

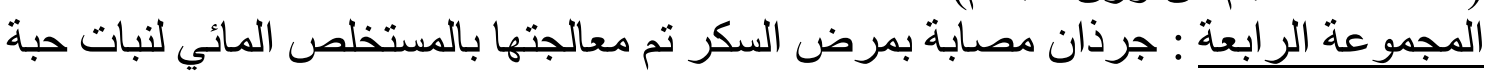

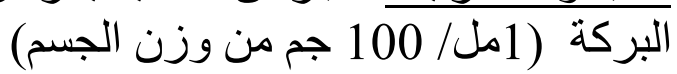

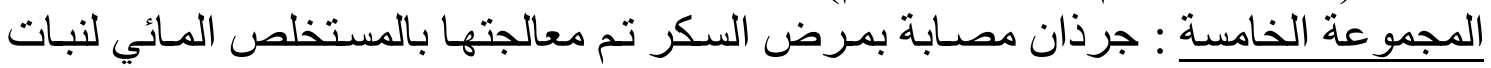

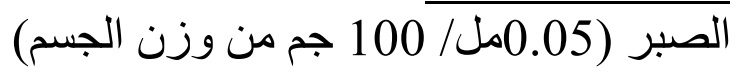
المجموعة السادسة : جرذان مصابة بمرض الجرض السكر تم معالجتها بالمستخلص المسائي لنبات

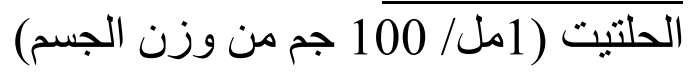

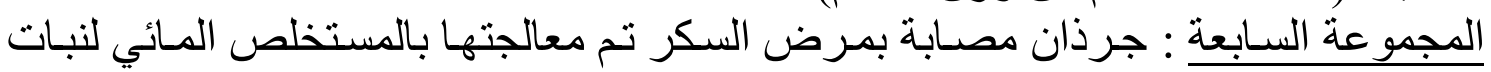

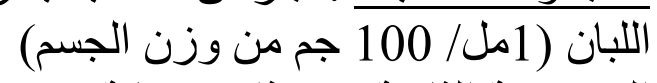
المجموعة الثامنة : جرذان مصابة بمرض وزن السكر تم معالجتها بالمستخلص المائي لنبات المر

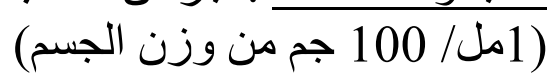
تم تقييم للتغير ات لصورة الدم بعد العلاج لمدة ثلاثون يوماو كذللك بعد فترة الاستشفاء ( بعد 15

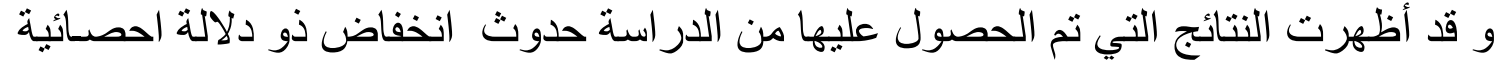

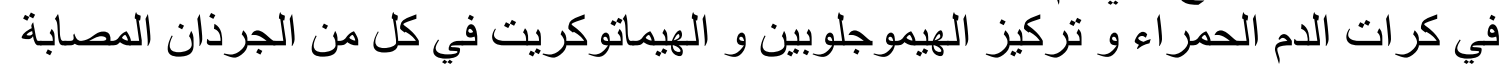

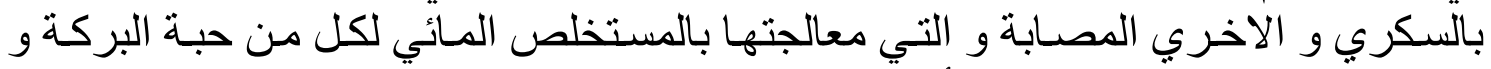

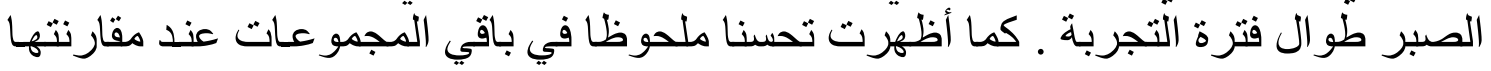

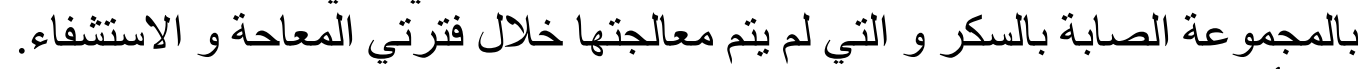

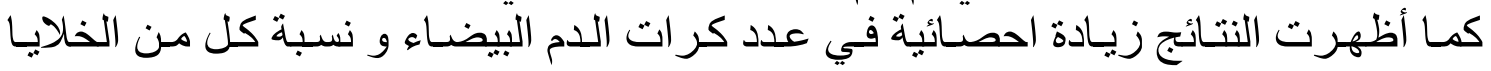

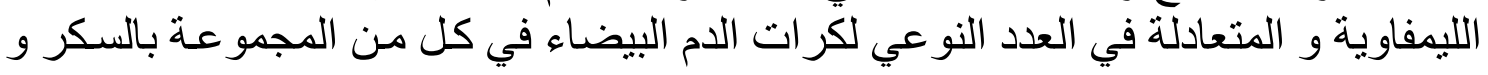


التي لم يتم معالجتهاو الاخرب المصـابة والتـي تم معالجتها بالمستخلص المـائي لنبـات الحلتيت . و لم تظهر باقي المجموعات المعالجة اي تغييرذو دلالة احصائيه.

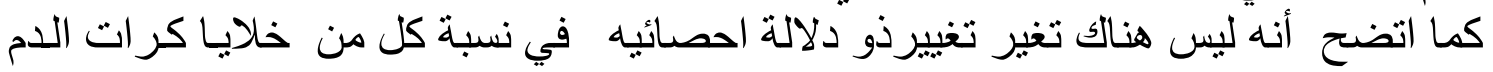

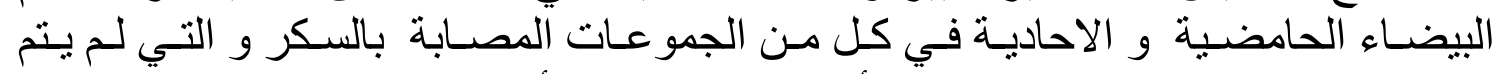
معالجتها و الاخري التي تم معالجتها بأي من هذه النها من النباتات أو الخليط منهر. 